\title{
Labor Migration Trend in Nepal
}

\section{Bishnu Prasad Pangali Sharma ${ }^{1,2}$, Chandra Kanta Baral ${ }^{3, *}$, Liladhar Sapkota ${ }^{4}$}

${ }^{1}$ State Key Laboratory of Remote Sensing Science, Aerospace Information Research Institute Chinese Academy of Sciences, Beijing 100101, China

${ }^{2}$ University of Chinese Academy of Sciences, Beijing 100049, China

${ }^{3}$ Department of Geography, Tri-Chandra Multiple Campus, Tribhuvan University, Kathmandu 44600, Nepal

${ }^{4}$ Central Department of Geography, Tribhuvan University, Kathmandu 44600, Nepal

* Corresponding E-mail: chandrakbaral30@gmail.com

\section{Article info}

Keywords:

Migration

Out-migration

Remittance

Pull and push factor

Household

Received: $4^{\text {th }}$ Aug. 2021

Accepted: $5^{\text {th }}$ Dec. 2021

DOI: https://doi.org/10.3126/ tgbv8i01.43488

(C) The Geographic Base

\section{Abstract}

Migration is one of the major factors affecting population distribution of Nepal. Job opportunity, education facility, medical facility and topographic situation are the key causes of migration. Human movement from mountain to hill; hill to Tarai; and rural to urban area migration are the major trend observed in Nepal. Migration has direct impact on various sectors including financial, social, demographic, and biological. All kind of services including educational, medical, transformational, and safety services should make equally accessible over the various parts of the country. This research helps to understand the trend of internal and international labor migration in Nepal. The study has used secondary data from Department of Foreign Employment (DoFE), Central Bureau of Statistics (CBS), Ministry of Finance (MoF). Remittance is playing a crucial role in the Nepalese economy. The highest foreign labor migration was found in the year 2013/14. The trend was continuously increased until 2013/14 and it has stated decreasing thereafter. International labor migration has mostly taken place to Malaysia, Qatar, Saudi Arabia, 
UAE and other Southeast Asian countries and it is growing over the time that has shifted the agricultural based economy towards remittance-based economy.

\section{Introduction}

Movement of people to a new area for better work and living is known as migration (Oxford, 2000). Migration affects demographic components including population size and growth of origin and destination. Nepal is a country where industrial growth is very limited, making fewer job opportunities. Migration, unlike fertility and mortality, is the least researched and understood component of demographic dynamics in Nepal even though many of Nepal's social and political problems are interwoven with the process of both internal and international migration $(\mathrm{KC}$, 1998). In terms of political boundary, migration is categorized as internal and international migration (Kansakar, 2012). Internal migration does not change the population of the country, but it does change the population of the specific place. Migration has a high impact on the growth and distribution of population and resources. Migration from Hill to Terai has immensely increased, generating pressure on the resource base of the Terai region. This has created imbalances in the distribution of land resources, which has long been the primary source of Nepal livelihood (Subedi, 2003). Internal migration has been common in Nepal and people generally migrate from Mountain, Hill to Terai region.
The large number of people from Nepal have migrated abroad in search of employment. The latest data suggests that a significant section of the total working population (around 7.3 per cent) work abroad (MoLE, 2016; CBS, 2011), and the remittance covers around 30 per cent of Nepal's GDP (World Bank 2016; Sijapati et al. 2012). The number of migrants and volume of remittance rising highly after the early 2000s (MoLE, 2016). Labor migration is one of the major sources of livelihood income besides agriculture in Nepal, where more than eighty percent work on agriculture. Besides all, poverty and lack of income opportunity in local are major causes of migration, which result in increasing migration for their livelihood (Kollmair, 2006).

Many people are migrating from developing countries to developed countries for a better employment opportunities and income (ILO, 2003). The formal and temporary migration began 'after people started to work in the British army following the Sugauli treaty that was signed on December 2,1815. This Treaty permitted Britain to recruit Gurkhas for military service' (Pant, 2006). Foreign employment is indeed the most significant motivation for international migration from Nepal in the twenty-first century. Migration for foreign employment has become a major source of income for many Nepali households (Mishra \& Kunwar, 2020; MoLE, 2016). Department of foreign employment (DoFE) shows that the 
number of migrants leaving Nepal for work is increasing every year. During the last fiscal year 2009/10 to 2018/19 more than 4564443 labor permits were issued to Nepalis to work abroad.

Malaysia, Qatar, Saudi Arabia, UAE and Kuwait are major destinations for Nepali migrants. The same report concluded that overseas employment is heavily male dominated: roughly $96 \%$ of all labor permits were given to men. At present labor migration diversity ranges from military recruitment, domestic work to semi-skilled works in different countries of Asia, Europe, and North America. Despite a long history of international labor migration in Nepal, the available information is very vague and incomplete (Bhandari, 2003). Foreign labor migration is now an intrinsic part of everyday life for a majority of Nepalese society, with its impact visible in every sphere of society - social, economic, cultural and even political (Seddon et al., 2001). Foreign employment has provided alternative livelihood opportunities, and remittances have helped to augment household incomes. The outflow of migrants in the past decade has been momentous in transforming the country's economic, social and cultural fabric. Nepal has emerged as a remittance economy, shaped by migrants' cash flows, so much so that it was the $23^{\text {rd }}$ largest recipient of remittances as a share of GDP in the world (Sah, 2019).

\section{Methods and Materials}

The main objective of the study is to find determinants and causes of migration, recent trend, and the impact of migration. To achieve the objectives, this study is based on secondary data. It is available with Ministry of labor and Transport Management (MoLTM), Department of Foreign Employment(DoFE), the Foreign Employment Promotion Board (FEPB), International Organization for Migration (IOM), Nepal Institute of Development Studies (NIDS), and Central Bureau of Statistics (CBS). The article comprises the trends in foreign employment for the past ten years, $2009 / 10$ to $2018 / 19$. The information from this report typically mentions the Nepali fiscal year (FY). It shows recent trends based on the past ten years.

The Microsoft excel is used for the analysis and preparation of graph and charts All the mapping work was done using ArcGIS software. We obtained spatial data from Department of Survey (DOS), Nepal. Only legal migrants migrated via international flights are considered as international migrants because it is impossible to keep records of the illegal migrants. Furthermore, the citizens of India and Nepal, both countries can travel and work freely across the border because of a bilateral friendship treaty signed between both the countries in 1950. 


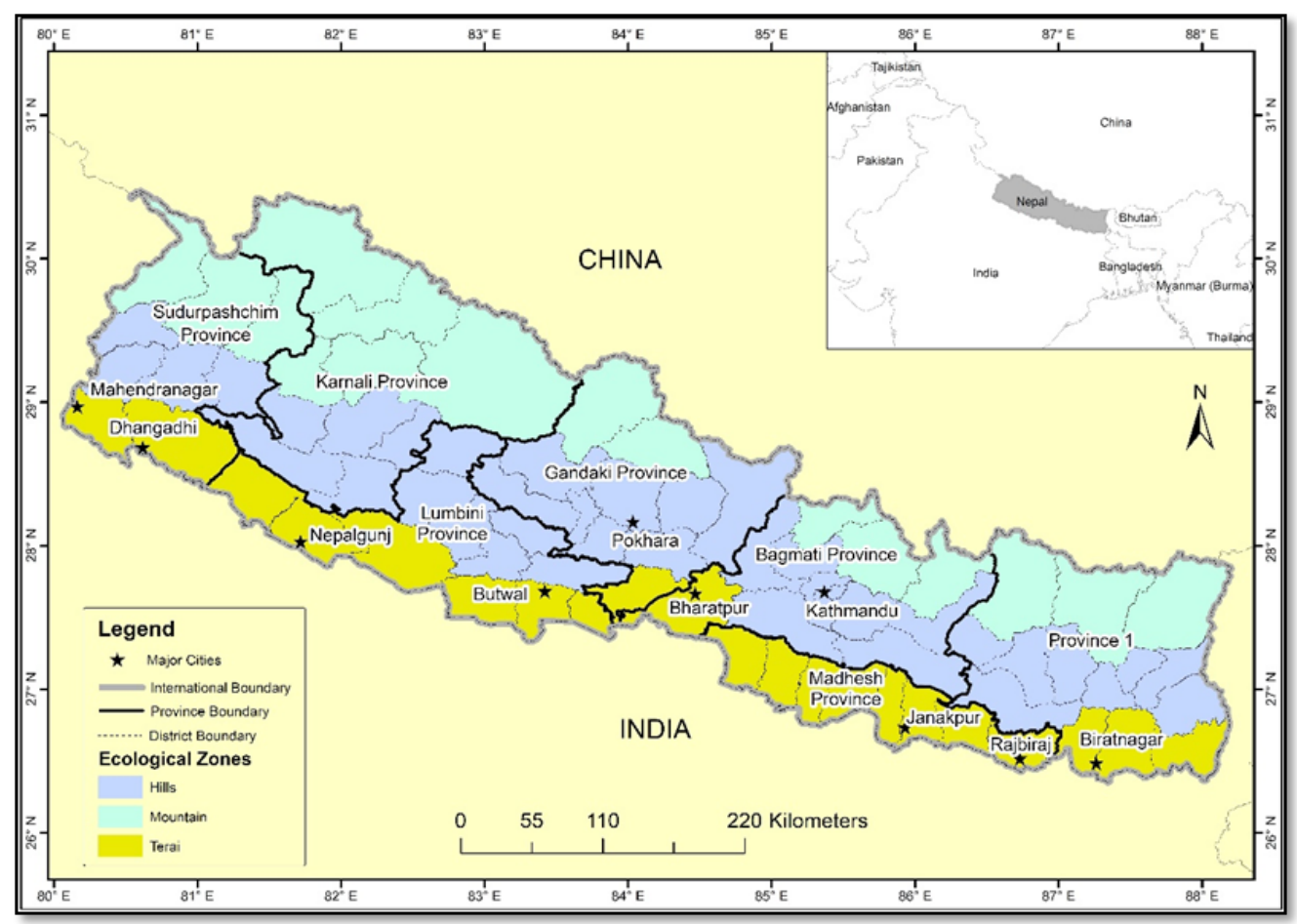

Figure 1. Location map of study area

The peoples do not need any documents and approval, and travel anytime due open, porous border and strong familial links. So, it is also hard to keep records of the peoples migrating to India. Since there is no exact and reliable record available regarding the migrants to India for any reason and government of Nepal does not formally keep record of those, the migrants to India are ignored in this study.

\section{Results and Discussion}

\section{Determinants of migration}

Migration is a complex phenomenon marked by socio-economic, political, cultural, demographic, environmental, and psychological causes in which push and pull factors work in the place of origin and the place of destination respectively. The pull factors are characterized by eradication of malaria, availability of fertile land, development of infrastructures, opportunities for employment, development of new technologies, better education, health, housing, entertainment, transportation and communication facilities, high demand for skilled manpower and physical labor, modern society, agglomeration of government and semi-government offices, developments of industries, business, trade, probity of constrictive works, high security of urban areas are 
the major factors to attract. The push factors are those which force to change from the place of origin to the destination place due to the existing hindrances. Push factors generally prevail because of insufficient fertile land in the Himalayas and mountains areas, and poverty, unemployment, semi-unemployment, religious, and social insecurity. Similarly, lack of transportation and communication, and infrastructure are other pull factors. Moreover, calamities like flood, landslides, droughts, famine, and epidemic diseases are also marked as natural causes.

\section{Causes of migration}

Migration is a complex process and has been a feature of human societies for many centuries. There are many reasons why people choose to migrate. Some of the reasons are discussed below.

\section{Physical conditions}

The bodily conditions of a place such as climate, soils may also be responsible for the migration of people, especially when such conditions are unfavorable. In the mountain region, the climate, condition of soil, topography is not good, so people from the mountain region choose to migrate to Terai and Hill regions.

\section{Differences in economic opportunities}

People tend to migrate where there are more economic opportunities like jobs enterprise transitions. In Nepal every year people migrate from mountains region and remote hilly region to Terai and cities. In search of education, job, and health and service many people migrate from different remote places of the country to urban areas. People generally migrate from the Hill to the Terai region due to food deficit, lack of employment opportunities, hard lifestyles, poverty, unfavorable conditions of relief and climate.

\section{Insecurity}

Fear of insecurity arise from war and political instability force people to migrate. During a decade long conflict in Nepal many people migrated to cities and Terai region. Similarly, political instability has also been a major reason for migration. This problem is further compounded by the hidden nature of displacement in Nepal, where people are forced from their homes either to merge into social networks of friends and families or to migrate with urban migrate route for district headquarters or the capital. Since the conflict started in the mid-1990s, hundreds of thousands of people uprooted across the country. Landowners' teachers, and other government employees have been specially targeted by the rebels and have fled their homes. The Asian Development Bank (ADB) suggested that between 300,000 to 400,000 rural families, or between 1.8 to 2.3 million people were displaced by the conflict since 1996 in Nepal (ADB, 2006). 


\section{Differences in group amenities}

Owing to dissimilarity in the availability of water, roads, and electricity, people tend to move where these amenities are available. In mountain region, people do not have facility of electricity and the same in the case with the people in

Table 1. Reason for migration in Nepal the remote rural areas of hilly region. Similarly, people have to walk hours to fetch water and there are not good roads connecting the people. So, people tend to move to areas where these faculties are available.

\begin{tabular}{|l|l|l|}
\hline Regions for migration & Percentage distributed by migration types \\
\hline A. Reasons related to the places of origin & In- migrants & Immigrants \\
\hline Lack of Job & 18.6 & 24.2 \\
\hline Landless & 14.7 & 10.8 \\
\hline Sale of land & 12.3 & 5.8 \\
\hline Lack of educational facilities & 7.7 & 6.7 \\
\hline Lack of business opportunities & 5.3 & 10.0 \\
\hline Migration of families & 4.4 & 0.8 \\
\hline Social and family's conflict & 1.4 & 3.3 \\
\hline Absence of relative at origin & 0.5 & 1.7 \\
\hline Sub- total & 64.9 & 63.3 \\
\hline Number of cases & 1137 & 76 \\
\hline B. Reasons related to the place of migration & & \\
\hline Better opportunities & 11.9 & 14.2 \\
\hline Service job transfer & 6.4 & 9.8 \\
\hline Owned land already & 2.7 & 0.8 \\
\hline Sub-total & 21.0 & 20.8 \\
\hline Number of cases & 367 & 25 \\
\hline C. Others & & \\
\hline No specific reason & 11.3 & 10.9 \\
\hline Don't know/ missing & 2.8 & 5.0 \\
\hline Sub-total & 14.1 & 15.9 \\
\hline Number of cases & 248 & 19 \\
\hline Total & 100 & 100 \\
\hline Number of cases & 1752 & 120 \\
\hline Source: & & \\
\hline
\end{tabular}

Source: Migration survey, 1996

The (table 1.) shows that the change of the place of the origin is mostly (18.6 percent) caused by the lack of employment opportunities, where 14.7 percent of people were landless followed by the sale of land (12.3). The survey record of 1996 has shown that among the destined migrants the highest was 11.9 percent for good employment facilities followed by 6.4 percent of people for reasons for service transfer. In total, inmigrants (64.9) and immigrations (63.3) were almost equal to change their place of origin characterized by push factors. 


\section{Trends of migration}

Internal migration has been very common in Nepal. Though it does not change the population of the country it changes the population and resource distribution of the specific areas. The shift of population from the Hill to Terai started first in the eastern parts of the country and the movement in the far western part only took place in the 1980s (Subedi, 1991). Several studies have been conducted in this field by different research institutions and scholars but most of these are concerned with the internal Hill to Terai and rural to urban types of migration (Gautam, 2006). It seems that the Terai can absorb the populations of hills for some time. There is still a relatively low agricultural density of the population. Therefore, the trend of population movement from the Hills to the Terai is not undesirable. More than 90 percent of all emigrants are from the hills and mountains of Nepal (Subedi, 1991). Another system of population migration is from ridges to the river valleys and structural basins in the Hills. The eastern hills have experienced the highest number of out-migrants in the country (Shrestha,1981). However, now the migration of people from eastern hills to Terai has decreased to a great extent. The adsorption of the eastern Terai has recently declined considerably. In the last decade, the migration of people from the hills of the far western region to Terai has been very common. Similarly, populations of city areas like Kathmandu, Pokhara, Bharatpur, Butwal, Lalitpur, Nepaljung, Dhangadhi, and Mahendranagar have been steadily rising in recent years. Moreover, the population of district headquarters of every district has been rising every year.
Table 2. Population Change in Nepal by Ecological Regions

\begin{tabular}{|l|l|l|l|l|l|}
\hline Region & 1971 & 1981 & 1991 & 2001 & 2011 \\
\hline Mountain & 9.9 & 8.7 & 7.8 & 7.3 & 6.7 \\
\hline Hill & 52.5 & 47.7 & 45.5 & 44.3 & 43 \\
\hline Terai & 37.6 & 43.6 & 46.7 & 48.4 & 50.3 \\
\hline Total & 100 & 100 & 100 & 100 & 100 \\
\hline
\end{tabular}

Source: CBS, Nepal (2011)

The population of mountains and hills have been decreasing while the population of Terai has been increasing. In 40 years, the population has decreased by 3.2 percent in the mountain region. The population of hilly region decreased by 9.5 percent, while the population of Terai regions increased by 12.7 percent.

(Table 3.) Shows that about 30 percent out-migration was from the mountains and 61.3 percent from the hills. The share of the eastern mountain alone was 22.7 percent. The hill out-migrants from the eastern, central, and western hills contributed 51.4 percent of the total outmigrants. The eastern and the central Terai regions constituted 65.3 percent of the net-migration. In the 1991 census, inter-regional migration increased from 1038862 to 1418206 . Mostly, the Terai region shared 14.2 percentage in 1991. The out-migration remarkably increased in the hills. Out- migrants in the 2001 census from the hills accounted for 66.9 percent which was lower than that of the 1991 census figure. Major streams of internal migration were rural to rural (62.2 percent) and rural to urban (25.5 percent) in 2001. Urban to urban and urban to rural migration streams were far less significant. 
Labor Migration Trend in Nepal...

Table 3. Trend of internal migration in Nepal

\begin{tabular}{|l|l|l|l|l|l|l|}
\hline \multirow{2}{*}{ Ecological region } & Census Year & \multicolumn{2}{|l}{ In- migration } & \multicolumn{2}{l|}{ Out-migration } & Net- migration \\
\hline \multirow{5}{*}{ Mountain } & 1971 & 9733 & $1.9 \%$ & 490092 & $9.8 \%$ & -399959 \\
\cline { 2 - 7 } & 1981 & 53628 & $5.2 \%$ & 315095 & $30.3 \%$ & -261467 \\
\cline { 2 - 7 } & 1991 & 39751 & $2.8 \%$ & 201406 & $14.2 \%$ & -161655 \\
\cline { 2 - 7 } & 2001 & 42727 & $2.1 \%$ & 297830 & $14.5 \%$ & -255103 \\
\cline { 2 - 7 } & 2011 & 45169 & $2.2 \%$ & 394,301 & $18.9 \%$ & $-349,132$ \\
\hline \multirow{5}{*}{ Hill } & 1971 & 72753 & $16.2 \%$ & 438719 & $86.6 \%$ & -359966 \\
\cline { 2 - 7 } & 1981 & 21197 & $20.4 \%$ & 636638 & $61.3 \%$ & -424711 \\
\cline { 2 - 7 } & 1991 & 267116 & $18.8 \%$ & 1021039 & $72.0 \%$ & -753923 \\
\cline { 2 - 7 } & 2001 & 540413 & $26.4 \%$ & 1371172 & $66.9 \%$ & -830759 \\
\cline { 2 - 7 } & 2011 & 588815 & $28.2 \%$ & 1311271 & $62.8 \%$ & $-722,456$ \\
\hline \multirow{5}{*}{ Terai } & 1971 & 418435 & $82.5 \%$ & 18510 & $3.7 \%$ & 399925 \\
\cline { 2 - 7 } & 1981 & 77307 & $74.4 \%$ & 87129 & $8.4 \%$ & 686178 \\
\cline { 2 - 7 } & 1991 & 1111339 & $78.4 \%$ & 195761 & $13.8 \%$ & 915578 \\
\cline { 2 - 7 } & 2001 & 1464210 & $71.5 \%$ & 378348 & $18.5 \%$ & 1085862 \\
\hline & 2011 & 1454186 & $69.6 \%$ & 382598 & $18.3 \%$ & 1071588 \\
\hline
\end{tabular}

Source: CBS, Population monograph of Nepal, (2014),

Table 4. Internal migration situation in the Kathmandu valley vis-à-vis the country's situation

\begin{tabular}{|l|l|l|l|l|l|l|}
\hline $\begin{array}{l}\text { Census } \\
\text { year }\end{array}$ & $\begin{array}{l}\text { Total population } \\
\text { of Kathmandu } \\
\text { valley }\end{array}$ & $\begin{array}{l}\text { Average } \\
\text { annual } \\
\text { growth rate of } \\
\text { Kathmandu } \\
\text { valley }\end{array}$ & $\begin{array}{l}\text { Average } \\
\text { annual } \\
\text { growth } \\
\text { rate of the } \\
\text { country }\end{array}$ & $\begin{array}{l}\text { Total } \\
\text { population } \\
\text { share of } \\
\text { Kathmandu } \\
\text { valley }\end{array}$ & $\begin{array}{l}\text { Population } \\
\text { density of } \\
\text { the country }\end{array}$ & $\begin{array}{l}\text { Population } \\
\text { density of the } \\
\text { Kathmandu } \\
\text { valley }\end{array}$ \\
\hline 1971 & $6,07,561$ & 2.1 & 2.1 & $5.3 \%$ & 79 & 676 \\
\hline 1981 & $7,66,820$ & 2.1 & 2.6 & $5.1 \%$ & 102 & 852 \\
\hline 1991 & $10,85,379$ & 2.9 & 2.1 & $5.9 \%$ & 126 & 1207 \\
\hline 2001 & $16,45,091$ & 3.4 & 2.2 & $7.1 \%$ & 157 & 1830 \\
\hline 2011 & $25,17,023$ & 3.5 & 1.4 & $9.5 \%$ & 180 & 2800 \\
\hline
\end{tabular}

Source: CBS, population census of Nepal (1971 to 2011). 
The Kathmandu valley has the highest number of migrants of any other city in the country. In 1971, the population of Kathmandu valley was 6,07,561 and its average annual growth rate was 2.1 percent, which was equal to the growth rate of the country. The valley here shared 5.3 percent of the total population of the country. The density of its population was 676 , while the country was only 79 . After forty years, in 2011 the population of the valley increased to $25,17,023$ and the annual growth rate increased to 3.5 . Similarly, the Kathmandu valley shared
9.5 percent of the total population of the country. In 2011, the population density of the country come to 180 while that of Kathmandu valley grew to 2800 .

\section{Yearly volume and trend of international labor migrants:}

The trend of international labor migration by fiscal year is presented based on the available government data from 2009/10 to $2018 / 19$. The trend analysis of labor migration is to observe the concentration of migrant workers by fiscal years.

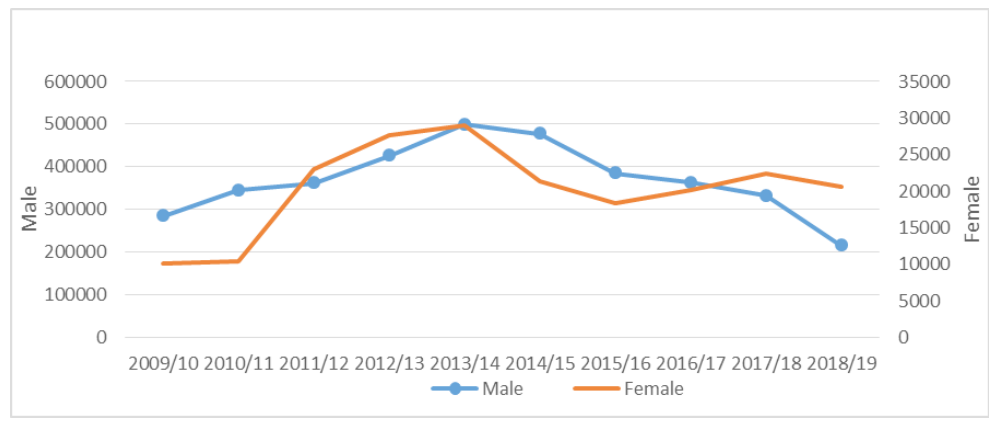

Figure 2. Volume and trend of international labor migrations

\section{Source: DoFE}

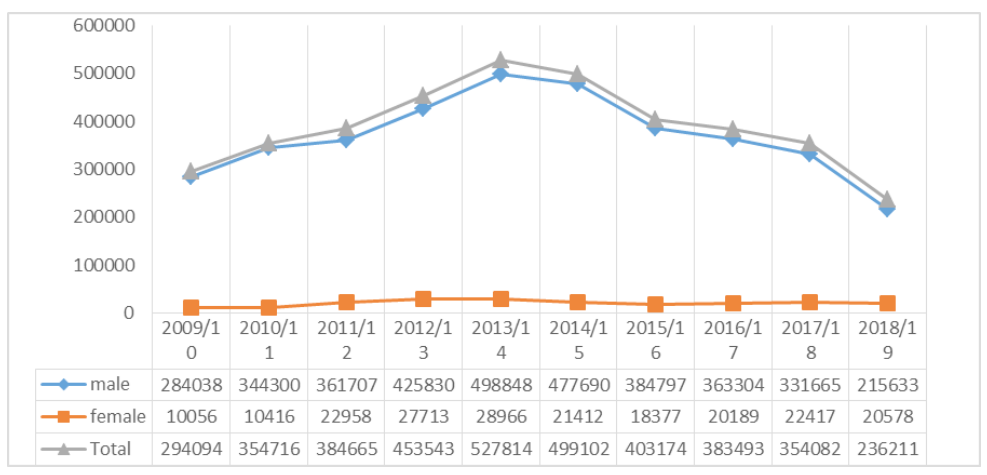

Figure 3. Volume and trend of international labor migrations

Source: DoFE 
Analyzing the data from $2009 / 10$ to $2018 / 19$, it is found that a total of 4564443 people went to foreign labor migrants from Nepal. The above data specifies the increasing trend of foreign labor migration, which is peaked at over 500000 . The rapid growth of international labor migrants can be observed in each year and the volume has also increased at the similar pattern. Similarly, the volume of labor migrations has declined since FY 2014/15.

\section{Destination of international labor migration}

The volume and trend of international labor migration by countries are also presented from $2009 / 10$ to $2018 / 19$. The volume analysis of labor migration is to observe the focus of migrant workers by country.

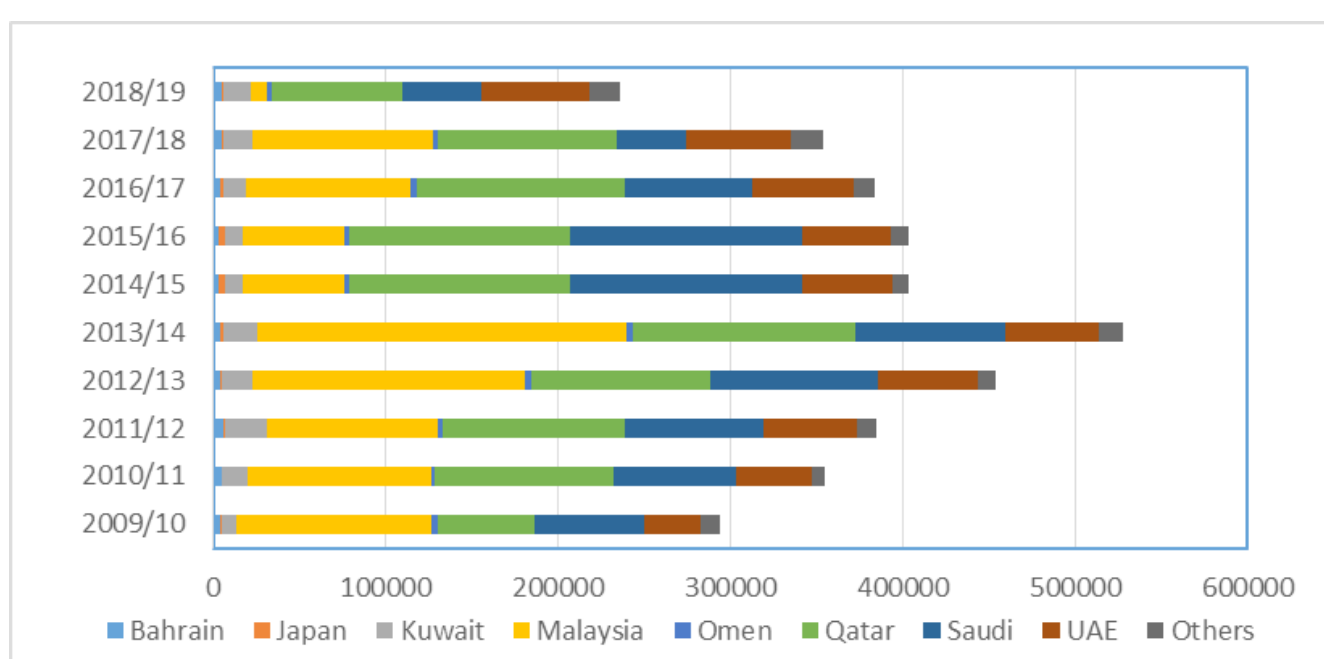

Figure 4. Volume and trend of international labor migration

\section{Source: DoFE}

According to Foreign Employment been fluctuating in the last decade, Information Management System (FEIMS) record (Figure 3.), labor approvals were obtained for a total of 128 countries in the FY 2018/19. The majority of Nepalese migrant workers went to Saudi Arabia, Malaysia, Qatar, Kuwait, omen and UAE every year. Labor migration to Malaysia has also peaking at over 200000 in 2013/14. The decline in the volume of workers to Malaysia in 2014/15, 2015/16 and 2018/19. Nepalese migrant workers have always highly concentrated in Quatar and second highly concentrated in Saudi and the third in UAE. 


\section{Provincial profiles of Nepal migrant workers}

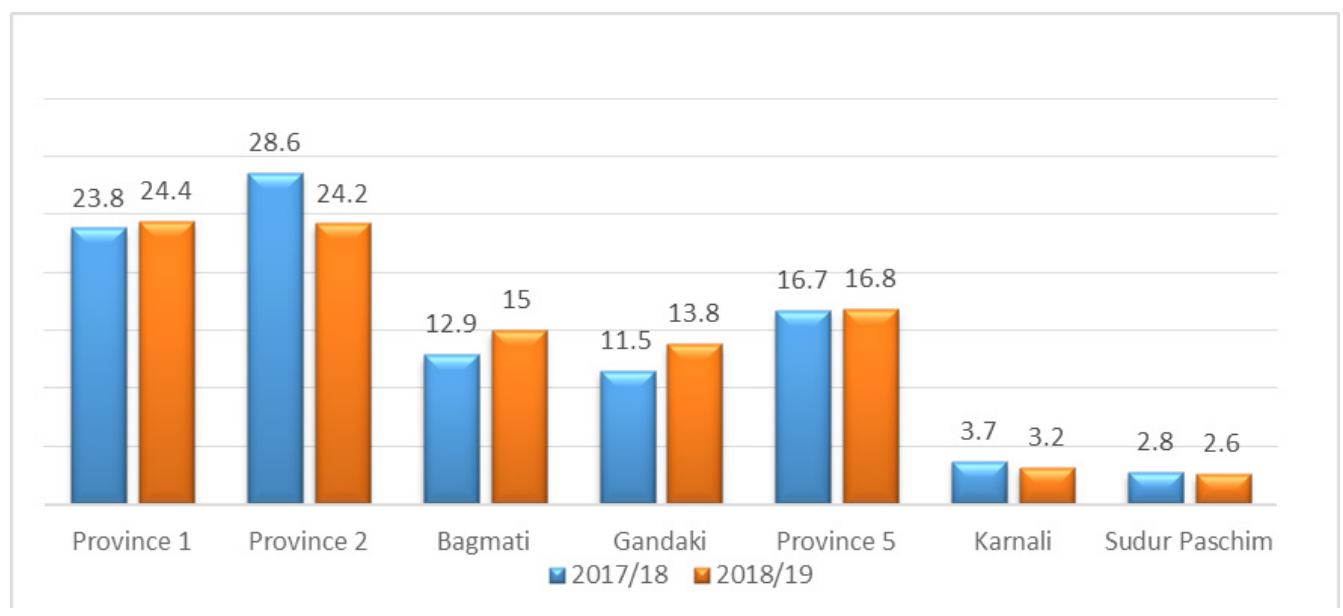

Figure 5. Province wise labor migration

Source: MoLESS, 2020

According to origin provinces, workers originated from Province 2 while province 1 and Madhesh province 23.8 Percent originated from province 1 observed the highest share of labor in 2017/18. Karnali and Sudur Paschim migration, comprising over 24 percent of the migrant's works each in 2018/19. almost 3 percent of total volume of migrant's workers in both years.

Similarly, 28.6 percent of migrant's

\section{International labor migration: skill wise}

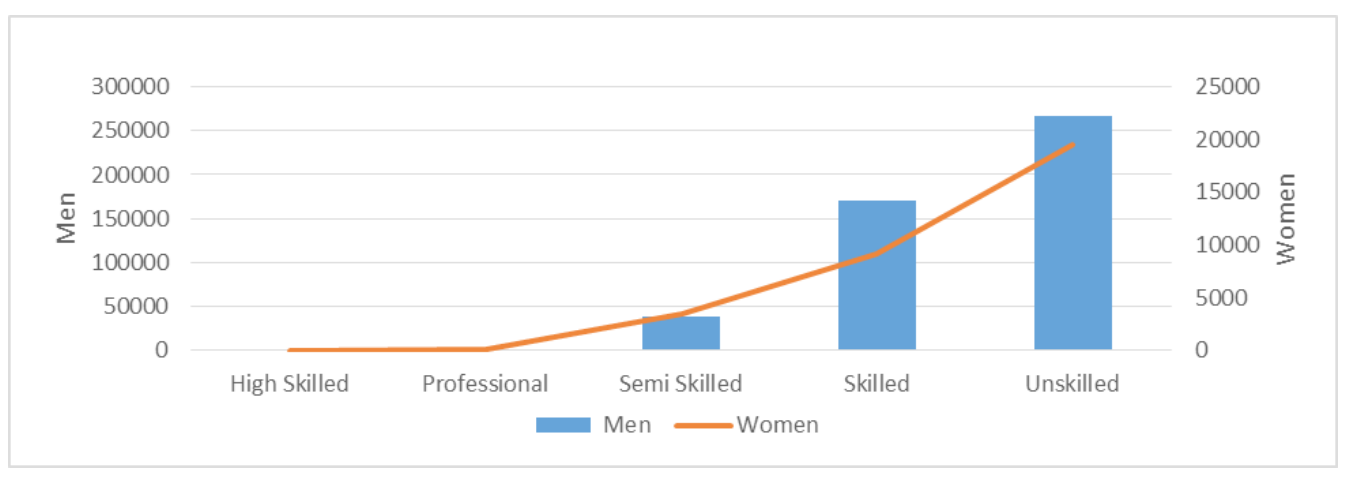

Figure 5. Skill wise international labor migration

Source: DoFE 
Skill development is a vital policy given its positive effect on labor output, poverty decrease, and economic growth. The work-related profile of labor migrants in $2018 / 19$ shows that $56 \%$ of total men and $61 \%$ of total women workers took up unskilled jobs. Similarly, skilled and semi-skilled male were $36 \%$ and $8 \%$, while the percentage of female were $28 \%$ and $11 \%$. But very less percent of labor migration was high skilled and professional skilled.

\section{Conclusion}

The lack of employment opportunity, education facility, health facility, and harsh topography are the main regions for migration. People usually migrate from mountains to hills and from hills to Terai. Migration has affected different sectors like economic, social, demographic, and biological. It is important to decentralize development to discourage migration. Moreover, development in all sectors is equally important to discourage internal migration. Education, health, transportation, and security services should be available in all parts of the country to lessen migration.

In terms of international labor migration, the majority of people go to Malaysia, Qatar, Saudi Arabia, UAE and other Southeast Asian countries for last 40 years, which has shifted the agricultural based economy of Nepal towards a remittance-based economy. The number of people going abroad for work have been decreased for the last few years.
Major concentration of Nepali migrant workers was in Gulf States from the very beginning, but the dynamics have been changed and people are migrating towards Malaysia till 2013/14 even though the number of people going to the Gulf States is still significant. Labor migration to Malaysia has peaking at over 200000 in 2013/14. The decline in the volume of workers to Malaysia in 2014/15, 2015/16 and 2018/19. Nepalese migrant workers are always highly concentrated in Quatar and second highly concentrated in Saudi and the third in UAE. Province 1 and Madhesh province observed the highest share of labor migration and province karnali and suderpachhim has observed lowest share of labor migrations. Most of the labor migrants are formal unskilled.

\section{References}

ADB. (2004). Nepal country strategy and program for 2005-2009, Kathmandu: Asian Development Bank, Nepal.

Bhandari, R.R. (2003). International labor migration as livelihood strategy: A case study of Prithvinagar VDC from eastern Terai of Nepal. Unpublished M.A. thesis submitted to Central Department of Geography, TU, Nepal.

Bhattarai, P. (2005). Migration of Nepalese youth for employment: Problems and prospects, A review of existing government policies and programs, Youth Action Nepal (YOAC), Kathmandu: Nepal.

Bista. K.B. (1977), Migration in Nepal: A Case Study of Far Western 
Development Region, TU Kirtipur Kathmandu, CEDA.

CBS. (2003). Population monograph of Nepal, Kathmandu: Central Bureau of Statistics. II, PP 1-35.

CBS. (2011). Population census 2011, Kathmandu: Central Bureau of Statistics.

CBS. (2011). Nepal living standards survey 2010/2011. Kathmandu: Central Bureau of Statistics.

DOFE. (2014). Economic survey 201314, Kathmandu: Ministry of finance Nepal.

Devkota, J. (2014). Impact of migrants' remittances on poverty and inequality in Nepal, Forum of International Development Studies, 44: 36-53.

Gautam, T. R. (2006). Causes and Impact of Migration: A Sociological Study of Emigration from Kandebash, Baglung, Nepal. Dhaulagiri Journal of Sociology and Anthropology, 1, 146-163. https://doi.org/10.3126/ dsaj.v1i0.285

Gyanwali, R.P. (2004). Socio-economic Aspects of Emigration: A case study of Baletaksar VDC of Gulmi District, Unpublished M.A. Dissertation of sociology, T.U. Kirtipur

ILO, (2003). Challenges to labor migration policy and management in Asia, (Geneva: ILO)

K.C. (1998). Trends, patterns and implication of rural to urban migration in Nepal, Kathmandu, Nepal. PP 101, Central Bureau of Statistics Government of Nepal, Kathmandu, Nepal.

K.C., B.K. (1997). Migration situation in Nepal, Central Department of Population Studies (CDPS), Tribhuvan University, Kirtipur.

Kansakar, V.B.S. (1974). Population change in Nepal: A study of mobility during 1911-1961, PH.D. Dissertation, Patna University.

Kansakar, V.S. (2012). History of population migration in Nepal, The Himalayan Review, Kathmandu, Nepal.

Kollmair, M., Manandhar, S., Subedi, B., and Thieme, S. (2006). New Figures for old Stories: Migration and Remittances in Nepal, In Migration Letters, An International Journal of Migration Studies, Volume 3, No. 2, pp. 151-160.

Lee, E.S. (1966). A theory of migration in demography, J.A. Jaskson (ed.), Cambridge University, London, Vol.3.

MoLE. (2016). Labor migration for employment. Kathmandu: Status report for Nepal 2014/15.

MOLESS. (2020). Migration report 2020, Kathmandu: Ministry of Labor, Employment and Social Security, Government of Nepal.

Mishra, M., \& Kunwar, L. S. (2020). Overview of Foreign Labor Migration in Nepal. Patan Pragya, 7(1), 123- 
134. https://doi.org/10.3126/pragya. v7i1.35114

Oxford. (2000). Oxford advanced learner's dictionary of current English, London: English language book society, United Kingdom.

Pant, B. (2006). Remittance inflows to Nepal: Economic impact and policy options, Economic review, occasional paper, April 2006, No 18, pp 20-35, Nepal Rastra Bank, Kathmandu.

Seddon, D., Adhikari J., and Gurung G. (2001). The New Lahures, Foreign Employment and Remittances Economy of Nepal, Kathmandu: Nepal Institute of Development Studies (NIDS).

Shrestha, C.B. (1981). Cultural geography of Nepal, Bhaktapur: Shrestha and Joshi.

Sijapati, B., A. Bhattarai, \& D. Pathak. (2015). Analysis of Labor Market and Migration Trends in Nepal. Kathmandu: Deutsche Gesellschaft für Internationale Zusammenarbeit (GIZ) $\mathrm{GmbH}$ and the International Labor Organization.

Stouffen, S.A. (1940). Intervening Opportunity. A Theory Relating to Mobility and Distance, American Sociological Review, Vol.5.

Subedi, B.P. (1991). International migration in Nepal, Towards an analytical framework, Contribution to Nepalese studies, (PP 83 -98). Kathmandu, Nepal. Center for Nepal and Asia Studies, Vol. 18 No.1 (TU: Kirtipur).

Subedi, B.P. (1993) Continuity and Change in Population Movement from Inside a Rural Nepali Community: An Unpublished Ph.D. Dissertation, Department of Geogrpahy, University of Hawaii, USA.

Subedi, B.P. (2003). International Labor Migration from Nepal. Emerging, Patterns and Trends, Comprehensive Change in Migration in Asia and Pacific Region, Kyoto, Department of Geography, Kyoto University,

Sunam, R.K., \& McCarthy, J. F. (2015). 'Reconsidering the links between poverty, international labor migration, and agrarian change: critical insights from Nepal'. The Journal of Peasant Studies, 43(1): 39-63.

Todaro, M.P. (1969). A model of labor migration and urban employment in less developed countries, American Economic Review, Vol 59,

World Bank. (2016). Large scale migration and remittance in Nepal, Kathmandu: Issues, challenges and opportunities. 